\title{
Qualitative and quantitative structural changes during pig oocyte maturation
}

\author{
D. G. Cran \\ AFRC Institute of Animal Physiology, Animal Research Station, 307 Huntingdon Road, \\ Cambridge CB3 OJQ, U.K.
}

\begin{abstract}
Summary. Pig oocytes were examined at hourly intervals after stimulation with hCG. Meiosis was resumed between 20 and $30 \mathrm{~h}$ after hCG. This coincided with a decline in the number of mitochondria and evidence is presented which indicates that this was due to fusion. The number of lipid droplets increased and the volume fraction of large vesicles decreased. Both these organelles maintained a close spatial relationship with the endoplasmic reticulum (ER). Mitochondria were clustered at the periphery of the cell before hCG injection but dispersed with maturation. The volume occupied by large vesicles, 'protein bodies' and Golgi also decreased at the edge of the oocyte with the progression of maturation.
\end{abstract}

\section{Introduction}

The acquisition of the ability of oocytes to undergo normal fertilization and subsequent development involves a progression of nuclear and cytoplasmic events. While maturation of the nucleus has a central role, it has been demonstrated that resumption of meiosis can occur spontaneously in culture (Pincus \& Enzmann, 1935; Edwards, 1965) without necessarily achieving competence for embryonic development (Thibault, Gerard \& Menezo, 1976).

During maturation, major changes take place in protein synthesis (McGaughey \& van Blerkom, 1977; Warnes, Moor \& Johnson, 1977; Moor \& Warnes, 1978; Crosby, Osborn \& Moor, 1981; Moor, Osborn, Cran \& Walters, 1981) and it has been proposed that such changes are essential for the continuation of cytoplasmic maturation (Thibault, 1977; Golbus \& Stein, 1978; Moor, Hay, Dott \& Cran, 1978). Structurally, the oocyte is a complex cell within which the organelles maintain specific spatial relationships. It has been demonstrated for the sheep (Cran, Moor \& Hay, 1980) and cow (Kruip, Cran, van Beneden \& Dieleman, 1983) that major structural rearrangements take place with maturation. Such changes are likely to be correlated with changes in protein synthesis and other, as yet, uninvestigated functions.

Information relating to structural changes during oocyte maturation in the pig is largely lacking, and there is little information of a quantitative nature for any species for the critical period after the LH surge. The present study examines changes in pig oocyte ultrastructure during maturation induced by hCG and provides quantitative information on such changes.

\section{Materials and Methods}

\section{Collection of oocytes}

Cross-bred gilts of the Large White and Landrace breeds, 8-10 months old, were injected intramuscularly with 1250 i.u. PMSG (Intervet Laboratories, Cambridge, U.K.) and $500 \mu \mathrm{g}$ cloprostenol (Estrumate: ICI, Macclesfield, U.K.) on the 15th day of the oestrous cycle (onset of oestrus $=$ Day 0 ) followed by 500 i.u. hCG (Intervet) $84 \mathrm{~h}$ after injection of PMSG. None of the 
animals had shown spontaneous oestrus before injection of hCG. To collect oocytes at specific times during maturation, gilts were anaesthetized and ovariectomized at $0,10,20,30$ and $40 \mathrm{~h}$ after hCG. Those follicles that had undergone stimulation were punctured and the cumulus masses flushed in Dulbecco's phosphate-buffered saline (Dulbecco \& Vogt, 1954) at $37^{\circ} \mathrm{C}$. Ovulation occurs in the pig 40-42 h after hCG (Dziuk \& Polge, 1962) and ovulated oocytes were collected $50 \mathrm{~h}$ after hCG by flushing the oviducts (Polge, 1982).

\section{Electron microscopy}

Fifty cumulus masses were processed for electron microscopy. After washing, the oocytes were

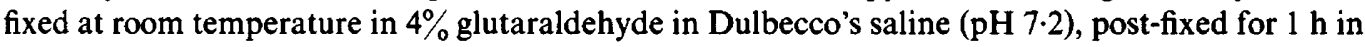
$1 \% \mathrm{OsO}_{4}$ in cacodylate buffer, block stained for $1 \mathrm{~h} \mathrm{in} 1 \%$ uranyl acetate in maleate buffer (pH 5.2) and embedded in Epon. Thick sections $(1 \mu \mathrm{m})$ were stained with $1 \%$ toluidine blue in $1 \%$ borax and thin sections with lead citrate.

Thick serial sections were cut through all the oocytes and at least 5 from each group were selected for ultrastructural examination. Thin sections were cut at at least two levels through each oocyte, one of which was through the nucleus and the other through the mid-point of the cell.

\section{Quantitation}

The entire visible area of the sections of the oocytes was photographed at a magnification of $\times 1600$ and montages made at a final magnification of $\times 3800$. In addition, extensive lengths of the perimeter were photographed at $\times 6300$ and montages made at $\times 15000$. A total length equivalent to the circumference of 2 entire oocytes was examined in this manner at each stage.

For montages of entire oocytes the volume fractions $(\mathrm{Vv})$ of mitochondria, lipid droplets and vesicles with a diameter $>1 \mu \mathrm{m}$, termed 'large vesicles', were determined by point counting using a lattice in which the points were separated by $1 \mathrm{~cm}$. The number of organelles per unit volume $(N \mathrm{v})$ was determined using the method of Weibel (Weibel \& Gomez, 1962) in which $N v=K / \beta \times$ $(N \mathrm{~A})^{3 / 2} /(V \mathrm{~V})^{1 / 2}$ where $K$ is a size distribution constant, $\beta$ a shape constant and $N$ A the number of organelles per unit area. Since the coefficient of variation of the size frequency distribution was $<25 \%$, $K$ was given a value of 1.05 (Williams, 1977). The value for $\beta$ is dependent on the ratio of the axes of the organelles. These were 1.0,1.53 and 1.44 for lipid droplets, mitochondria and large vesicles respectively $(n=100)$. These were accordingly given values of $\beta$ of $1.382,1.446$ and 1.427, determined from the graph given by Weibel (1969). The cytoplasmic areas were traced, weighed and calculated from a standard.

Values of $N \mathrm{v}$ were also determined for mitochondria present within $6 \mu \mathrm{m}$ of the oocyte plasma membrane. In addition, $V \mathrm{v}$ values in this part of the cell for large vesicles, membranous constituents comprising endoplasmic reticulum (ER) and small vesicles, Golgi bodies, and 'protein' bodies were calculated. $N \mathrm{v}$ was not determined for these organelles since they either did not consist of discrete entities or their dimensions were such that sections of entire organelles were frequently not included in micrographs taken at this magnification.

\section{Results}

\section{Generalized structure}

Apart from the nucleus the most prominent organelles in the pig oocyte were membrane-bound vesicles (large vesicles), lipid droplets and mitochondria. The membrane-bound vesicles which formed up to $15 \%$ of the oocyte volume measured $1.3 \pm 0.3 \mu \mathrm{m}$ (s.e.m. $)(n=100)$ in diameter. They were generally electron lucent (Pl. 1, Fig. 1) with occasional amorphous and membranous contents. A characteristic feature of such vesicles was an intimate relationship with the ER. This took the 

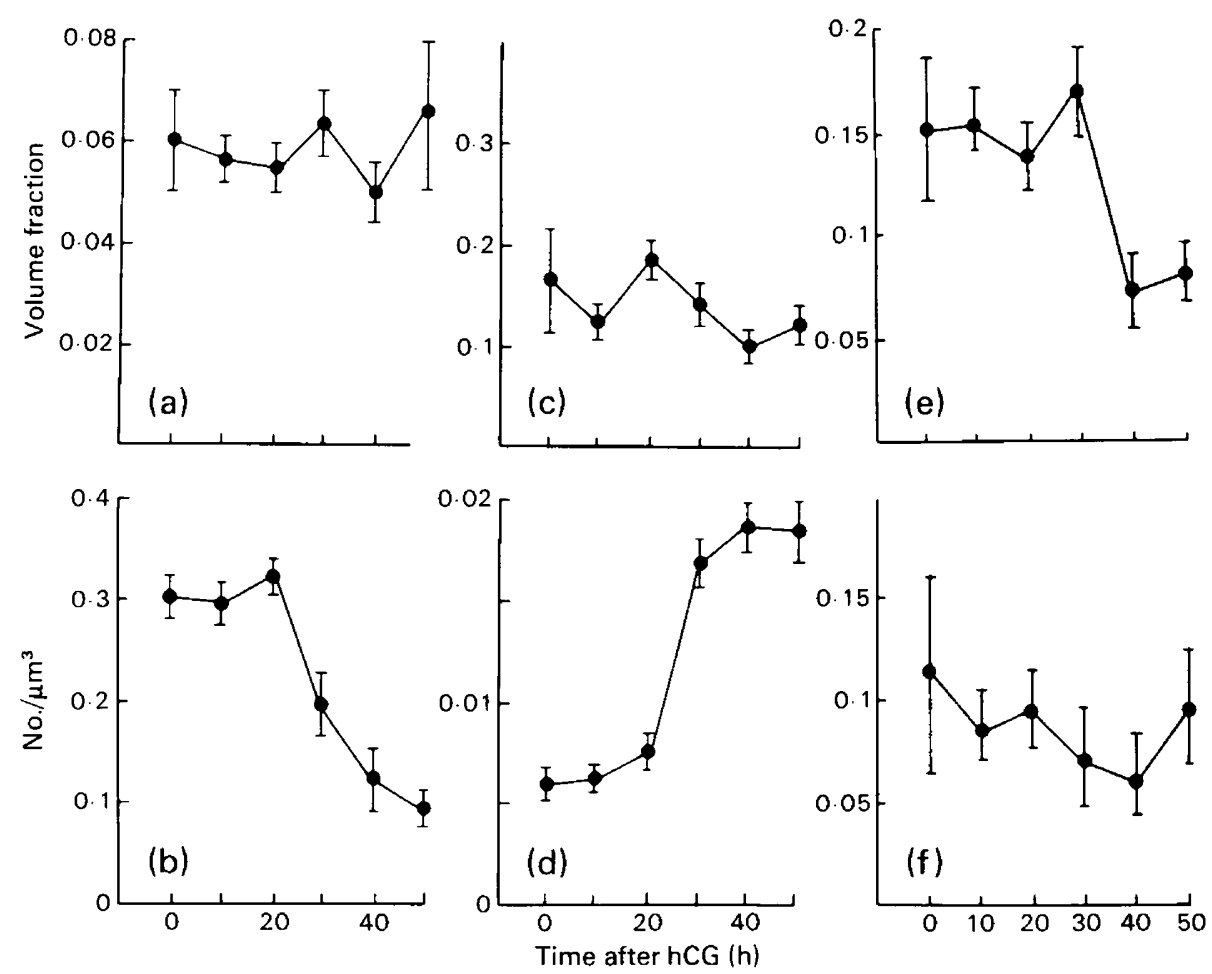

Text-fig. 1. Volume fraction $(V \mathrm{v})$ and number $/ \mu \mathrm{m}^{3}(N \mathrm{v})$ of mitochondria (a \& b), lipid droplets (c \& d) and large vesicles (e \& f) in whole pig oocytes after hCG.

form of a close apposition of smooth ER along part of the boundary of the vesicles (P1. 1, Fig. 1). The lipid droplets which had an average diameter of $3.3 \pm 0.2 \mu \mathrm{m}$ represented up to $20 \%$ of the cell volume. The structural appearance and dimensions of the lipid droplets varied with the stage of maturation (see below) and also maintained a close spatial relationship with the ER, which frequently formed an enclosing sheath (Pl. 1, Fig. 2). The mitochondria were similar to those observed in other domestic species, containing few cristae and frequently apposed vesicular or cisternal ER (Pl. 1, Fig. 3). Unlike the mitochondria of sheep and cattle oocytes (Senger \& Saake, 1970; Fleming \& Saake, 1972; Russe, 1975; Cran et al., 1980), hooded forms were infrequent.

Golgi bodies were present in a peripheral position or adjacent to dictyate nuclei. Cortical granules were confined to the first $4 \mu \mathrm{m}$ of cortical cytoplasm throughout maturation. Ribosomes were either in the form of rosettes or infrequently on rough ER and did not have any preferential distribution. An unusual structure formed by dilatation of rough ER (Szollosi \& Hunter, 1973) was present throughout the cytoplasm (P1. 1, Fig. 4). These took the form of vesicles ranging in diameter from 0.5 to $1.0 \mu \mathrm{m}$. They frequently bore ribosomes on their external surface and for the sake of ease of description have been termed 'protein bodies' although the nature of their contents remains to be determined. The frequency of such ribosomes was less than in oocytes from unstimulated animals (Pl. 1, Fig. 5). In addition, protein bodies from stimulated animals were less electron dense than those from unstimulated pigs.

\section{Quantitative changes}

Whole oocyte. The volume fraction occupied by mitochondria remained constant throughout maturation (Text-fig. 1a) at about 0.06 (i.e. $6 \%$ ). While the mean number was constant at $0.3 / \mu \mathrm{m}^{3}$ 
for the first $20 \mathrm{~h}$ after hCG there was a decline to $0 \cdot 2 / \mu \mathrm{m}^{3}$ by $30 \mathrm{~h}$, reaching $0 \cdot 1 / \mu \mathrm{m}^{3}$ by $50 \mathrm{~h}$ (Textfig. 1b).

There was considerable variation in the $V \mathrm{v}$ value for lipid both within and between groups of oocytes (Text-fig. lc) and there was no correlation for this measurement with time after hCG, the proportion of the cells occupied varying between 10 and $20 \%$. As with the mitochondria, the number of lipid droplets remained constant for the first $20 \mathrm{~h}$ at about $0.007 / \mu \mathrm{m}^{3}$ (Text-fig. $1 \mathrm{~d}$ ). There was a rise thereafter such that by $30 \mathrm{~h}$ there were about 0.016 lipid droplets $/ \mu^{3}$.

The volume fraction of large vesicles remained constant up to $30 \mathrm{~h}$ after hCG at about $0 \cdot 15$ (Text-fig. 1e). At $40 \mathrm{~h}$ this had declined to 0.075 . There was considerable variation in vesicle number throughout oocyte maturation and no significant changes in this characteristic were detected (Text-fig. 1f).

Oocyte periphery. At $0 \mathrm{~h}$ there were $0.9 / \mu \mathrm{m}^{3}$ mitochondria present at the edge of the oocyte (Text-fig. 2) compared with a mean of $0 \cdot 3 / \mu^{3} \mathrm{~m}^{3}$ for the entire cell. This was followed by a decline which was greatest between 30 and $40 \mathrm{~h}$ such that, at $50 \mathrm{~h}, 0 \cdot 1 / \mu \mathrm{m}^{3}$ were present, a value similar to that for the entire oocyte at this stage (Text-fig. 1b).

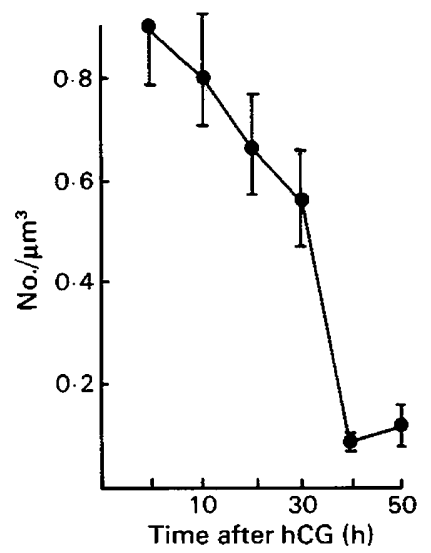

Text-fig. 2. $N \mathrm{v}$ of mitochondria in the periphery of pig oocytes after treatment with hCG.

The volume fraction occupied by vesicles was less than for the entire oocyte $\left(0 \cdot 1 \mu \mathrm{m}^{3}\right.$ compared with $0 \cdot 15 \mu \mathrm{m}^{3}$ ) and declined significantly by $30 \mathrm{~h}$ (Text-fig. 3a). There was considerable variation in the volume fraction occupied by membranous elements (ER and small vesicles) between oocytes taken at the same time after hCG. At $0 \mathrm{~h}$ a value of $0.14 \pm 0.06$ was obtained, while at $40 \mathrm{~h}$ this was

\section{PLATE 1}

Fig. 1. At $20 \mathrm{~h}$ after $\mathrm{hCG}$. Membrane bound large vesicles (V) with flocculent (F) or membranous (M) contents. Three of the vesicles show a close relationship with ER (arrows). Multicisternal Golgi bodies (G) are also present. $\times 18000$.

Fig. 2. At $0 \mathrm{~h}$. Lipid droplet with bounding layer of ER (ER). A few electron-lucent streaks (arrows) are present. $\times 18000$.

Fig. 3. At $20 \mathrm{~h}$ after hCG. Mitochondrial grouping at the cell periphery demonstrating the association with vesicular (V) and cisternal (C) ER. $\times 10000$.

Fig. 4. At $40 \mathrm{~h}$ after hCG. 'Protein body': a few ribosomes $(\mathrm{R})$ are present on the bounding membrane. $\times 39000$.

Fig. 5. Oocyte from an unstimulated pig. 'Protein body' showing numerous attached ribosomes. $\times 25000$. 
PLATF 1
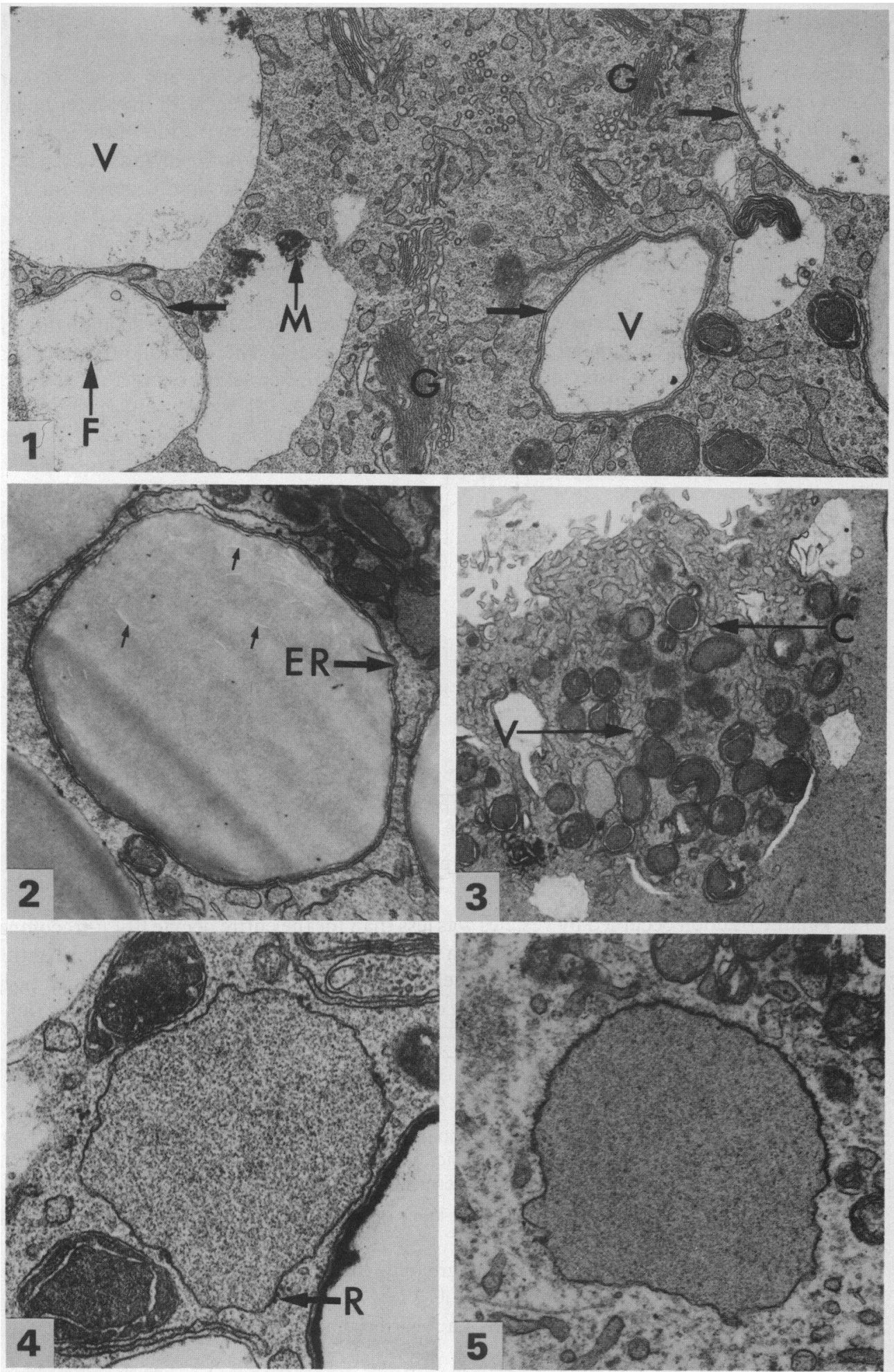

(Facing p. 240) 

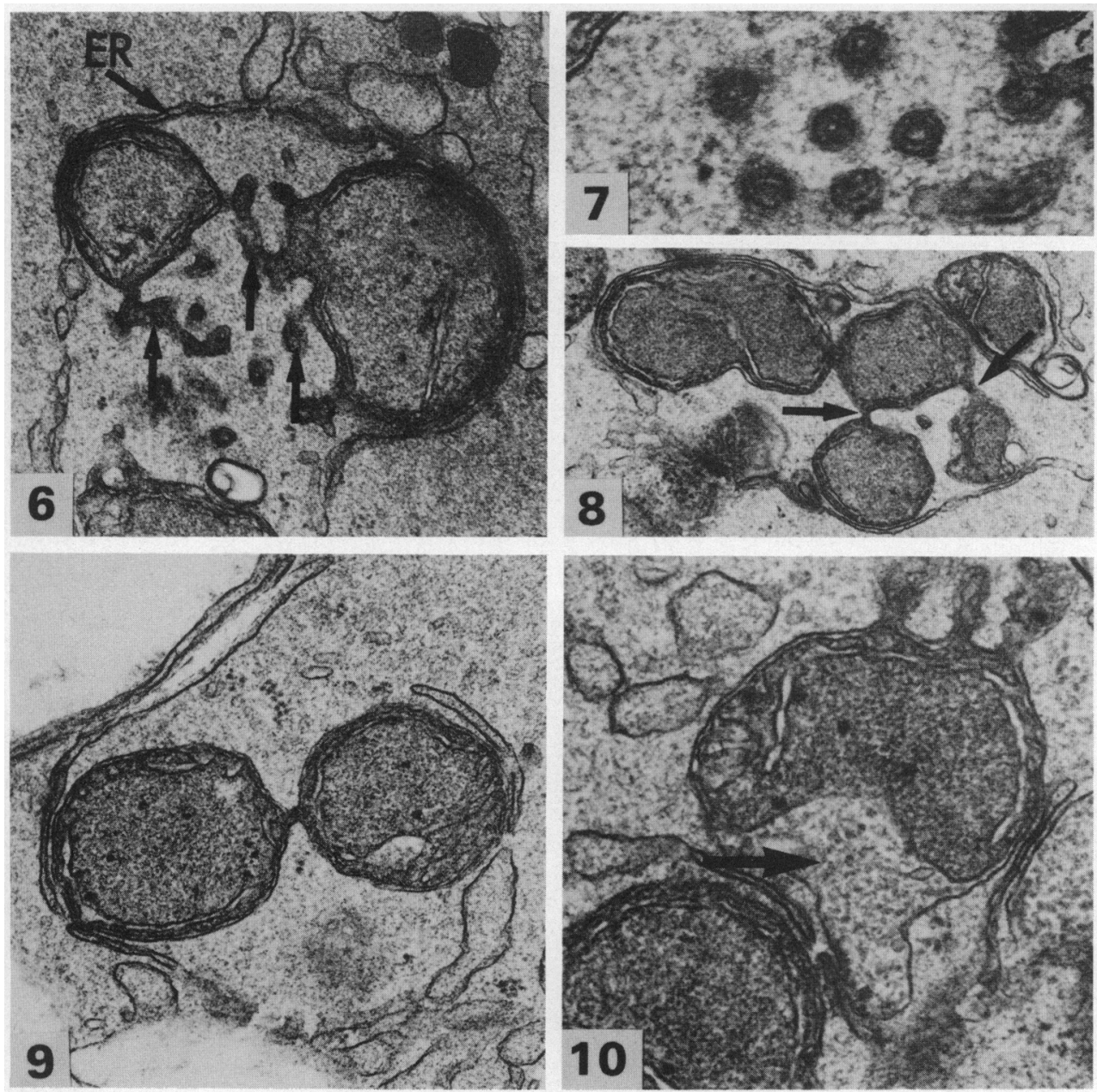

Fig. 6. At 40 h after hCG. A group of 3 mitochondria enclosed by ER (ER). The mitochondrial envelopes show marked protrusions (arrows). $\times 41000$.

Fig. 7. At $40 \mathrm{~h}$ after hCG. Cross-section through mitochondrial protrusions. Note the uniformity of the profiles. $\times 80000$.

Fig. 8. At $40 \mathrm{~h}$ after hCG. A mitochondrial grouping in which 3 are connected by narrow bridges (arrows). $\times 24000$.

Fig. 9. At $40 \mathrm{~h}$ after hCG. Two mitochondria connected by a narrow neck. $\times 38000$.

Fig. 10. At $40 \mathrm{~h}$ after hCG. Mitochondria with a markedly dilated envelope (arrow). It also bears protrusions of its envelope. $\times 61000$. 
PLATE 3
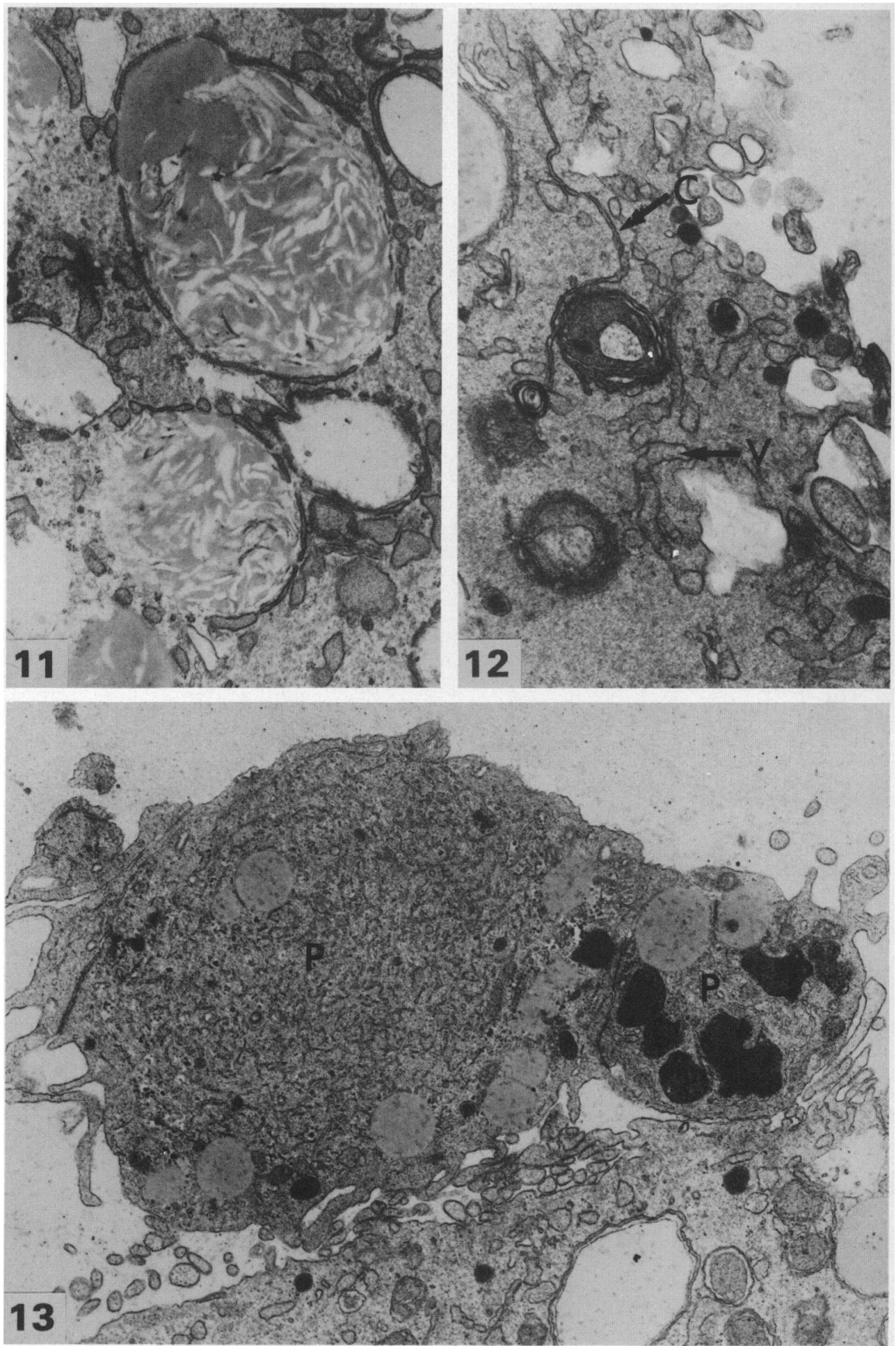


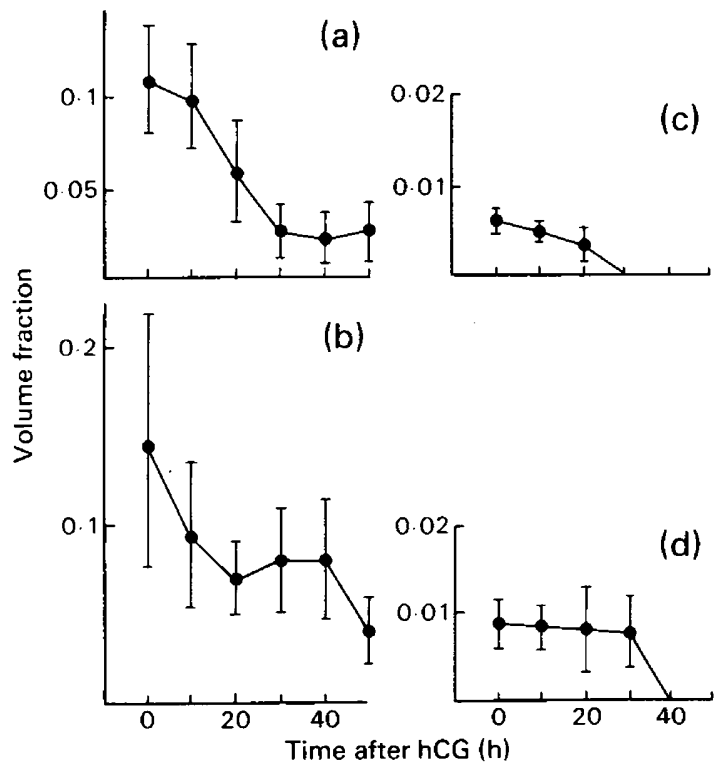

Text-fig. 3. $V v$ of large vesicles (a), ER and small vesicles (b), Golgi (c) and 'protein bodies' (d) in the periphery of pig oocytes after treatment with hCG.

Table 1. State of meiotic maturation of pig oocytes after treatment with hCG

\begin{tabular}{ccl}
\hline $\begin{array}{c}\text { Hours } \\
\text { after hCG }\end{array}$ & $\begin{array}{c}\text { No. of } \\
\text { oocytes }\end{array}$ & $\begin{array}{c}\text { Maturational } \\
\text { stage }\end{array}$ \\
\hline 0 & 13 & Germinal vesicle \\
10 & 7 & Germinal vesicle \\
20 & 7 & Germinal vesicle \\
30 & 8 & Metaphase I-II \\
40 & 7 & Metaphase II \\
50 & 8 & Metaphase II \\
\hline
\end{tabular}

$0.08 \pm 0.03$. Although there was a downward trend this barely reached significance (Text-fig. $3 \mathrm{~b}$ ). The Golgi remained constant for the first $20 \mathrm{~h}$ (Text-fig. 3c) and the 'protein bodies' for the first 30 $h$ (Text-fig. 3d). Thereafter, neither of these organelles was present within the oocyte periphery.

\section{Qualitative changes}

The nuclei of all oocytes up to $20 \mathrm{~h}$ after hCG were in the germinal vesicle stage. The mean nuclear diameter was $30 \mu \mathrm{m}$. Since the pig oocyte has a diameter of $\sim 110 \mu \mathrm{m}$, the germinal vesicle

\section{PLATE 3}

Fig. 11. At $50 \mathrm{~h}$ after hCG. Lipid droplets containing numerous electron-lucent streaks. The bounding ER is discontinuous. $\times 14000$.

Fig. 12. At $40 \mathrm{~h}$ after hCG. Cisternal ER (C) is close to the oolemma and vesicular ER (V) is also presẹnt. $\times 46000$.

Fig. 13. At $20 \mathrm{~h}$ after hCG. Degenerating ends of somatic cell processes (P). No junctional contact is evident. $\times 16000$. 
represents $\sim 2 \%$ of the total volume. At $30 \mathrm{~h}$ the nuclei were in metaphase I or telophase I while those at 40 and $50 \mathrm{~h}$ were in metaphase II (Table 1).

At $0 \mathrm{~h}$, as was also indicated by the quantitative data, the mitochondria, which had a mean diameter of $0.41 \pm 0.01 \mu \mathrm{m}$, were aggregated towards the edge of the oocyte. With maturation, these and the large vesicles dispersed, resulting in, at $40 \mathrm{~h}$ and $50 \mathrm{~h}$, a cortical region which was relatively organelle free. At this stage the mitochondria measured $0.62 \pm 0.02 \mu \mathrm{m}$. Up to $30 \mathrm{~h}$ the mitochondria tended to occur in small groups with associated ER (Pl. 1, Fig. 3). From $30 \mathrm{~h}$ they became progressively associated with sheet-like cisternae of the type adjacent to lipid droplets and large vesicles (PI. 2, Fig. 6). In addition, the cisternae were frequently related to groups of 2 or 3 mitochondria (Pl. 2, Figs 6 \& 8). From $30 \mathrm{~h}$ marked finger-like blebbing of the mitochondrial outer chamber was observed (PI. 2, Figs 6, $7 \& 8$ ). In addition, the mitochondria were also often linked by narrow bridges (Pl. 2, Figs 8 \& 9). Generally only two mitochondria as seen in thin section were involved in the association, but occasionally three or more were linked (Pl. 2, Fig. 8). At $40 \mathrm{~h}$ and 50 $\mathrm{h}$ after hCG mitochondria with markedly dilated outer chambers were also present (Pl. 2, Fig. 10).

The lipid droplets at 0 to $20 \mathrm{~h}$ had a generally uniformly grey image and measured $3.4 \pm 0.2 \mu \mathrm{m}$. At $30 \mathrm{~h}$ some contained many electron-lucent streaks. This form increased in frequency with time such that by $50 \mathrm{~h}$ after hCG virtually all the lipid was of this form (Pl. 3, Fig. 11). Lipid droplets in such oocytes had a mean diameter of $3 \cdot 0 \pm 0 \cdot 2 \mu \mathrm{m}$. In addition, while at $0 \mathrm{~h}$ the droplets were generally totally enclosed by ER, at 40 and $50 \mathrm{~h}$ the association was more fragmentary (Pl. 3, Fig. 11).

Up to $20 \mathrm{~h}$ Golgi comprising several cisternal layers were present close to the plasma membrane and the nucleus and occasionally in deeper regions of the cell (Pl. 1, Fig. 1). After $20 \mathrm{~h}$ this form of Golgi was no longer observed. However, at this time extensive lengths of ER running parallel to the plasma membrane were present at the periphery of the oocytes (Pl. 3, Fig. 12). Occasional dilatations of such ER were associated with small vesicles and cortical granules.

Processes from somatic cells were in contact with the oolemma by intermediate junctions up to $20 \mathrm{~h}$ after hCG. However, at this time swollen remnants of processes lacking junctional contact were also present (Pl. 3, Fig. 13). After this time no junctional contact was evident.

\section{Discussion}

The morphological changes in the pig oocyte during maturation may be broadly divided into two phases; a phase before about $20 \mathrm{~h}$ after hCG and the subsequent period up to ovulation. In the first phase the nucleus remained in the germinal vesicle stage while in the second, nuclear maturation took place. During the first phase both the volume fraction and the number of mitochondria, lipid droplets and large vesicles remained constant. In the second phase, there was an abrupt change in these characteristics. Superimposed upon these changes were redistributional events and qualitative changes of organelles.

In the cow (Kruip et al., 1983) and sheep (Cran et al., 1980; Moor, Polge \& Willadsen, 1980) morphological and functional events may be broadly related to germinal vesicle breakdown (GVBD). In these two species the time leading up to GVBD is about 6 and $9 \mathrm{~h}$ respectively. This phase has been termed the "inductive" period (Moor et al., 1980) and it has been demonstrated that during this period the oocyte requires follicle cell support (Moor et al., 1980). In the pig junctions between follicle cell processes and the oocyte were present up to 20-30 h after hCG. After GVBD in the sheep, there was a period of some $12 \mathrm{~h}$, the "synthetic" period during which follicle cell support was not required (Moor et al., 1980). In the pig the "inductive" phase appears to be particularly prolonged. Fertilization, however, can be achieved some $40 \mathrm{~h}$ after the LH surge (Hancock, 1959). The "synthetic" period in the pig may therefore be of a duration similar to that in the sheep and cow. 
The timing of the onset of meiosis is similar to that reported by others (Spalding, Berry \& Moffit, 1955; Hunter \& Polge, 1966; Ainsworth, Tsang, Downey, Marcus \& Armstrong, 1980) and corresponds with a marked decline in follicular fluid oestrogen levels and also with cumulus expansion (Ainsworth et al., 1980). While there is little evidence for the induction of meiosis through hormone stimulated steroidogenesis (Foote \& Thibault, 1969; Tsafriri, Lindner, Zor \& Lamprecht, 1972; Lieberman et al., 1976) it is clear that initial high levels of oestrogen are necessary for the cytoplasmic maturation required for subsequent embryonic development (Moor \& Trounson, 1977; Moor, 1978; Moor et al., 1980). The nature of the signals passing between the two cell types is still obscure. However, the rapid change in oocyte metabolism evidenced by the alteration in organelles together with the onset of meiosis would suggest the presence of a strict control mechanism.

During maturation there was a decline in mitochondrial number such that at $50 \mathrm{~h}$ after hCG there was only one third the number at $0 \mathrm{~h}$. Concomitantly, there was no change in the volume fraction indicating an increase in mitochondrial size, and direct measurements showed that over this period there was a $>300 \%$ increase in individual mean mitochondrial volume. There are two processes which might explain the loss of mitochondria; degeneration or fusion. While the observed dilatation of the mitochondrial envelope may be an indication that some loss of mitochondria by degeneration was taking place, few markedly degenerate organelles were observed. It seems unlikely, therefore, that the reduction in number may be accounted for by this means. After GVBD small groups of mitochondria become enveloped in cisternae of ER and also developed numerous extensions. In addition dumb-bell-shaped configurations were observed. In view of the numerical data, it is unlikely that these represent fission. It is rather more likely that they were indicative of fusion. The physiological significance of these changes is not clear. Dekel, Hultborn, Hillensjo, Hamberger \& Kraicer (1976) demonstrated a decline in oxygen consumption during maturation of mouse cumulus-oocyte complexes. However, the majority of oxygen consumption may be accounted for by that of the somatic cells, although Magnusson, Hillensjo, Tsafriri, Hultborn \& Ahren (1977) have indicated that the maturation of denuded oocytes elicits an increase in oxygen consumption which is correlated with the onset of meiosis. The present observation may therefore be a structural manifestation of this change in metabolism.

Before hCG the number of mitochondria in the oocyte periphery was some 3-fold greater than the average for the entire cell. Following hCG this declined progressively, eventually reaching levels found elsewhere in the cytoplasm. Congregation of mitochondria close to the plasma membrane of non-matured oocytes is a common feature (Sotelo \& Porter, 1959; Hadek, 1969; Fleming \& Saake, 1972; Cran et al., 1980; Kruip et al., 1983) and may represent an economical position for processing molecules entering the cell. The movement to the interior may represent a loss of dependency of the follicular environment and appears to precede loss of intercellular coupling.

A close inter-organelle relationship, particularly between mitochondria and the ER is a common feature in mammalian oocytes (Fleming \& Saake, 1972; Cran et al., 1980; Kruip et al., 1983). The relationship between the ER and lipid and the large vesicles may, however, be unique to the pig. Since the ER is a site of protein manufacture and transport, such an association may be indicative of a phospho-protein content within the droplets. However, the significance of such associations, the change in structure of the lipid droplets with oocyte maturation and the potential for the ER to exert a controlling influence on product utilization and intracellular transport must await the appropriate biochemical evidence.

As in the cow oocyte (Kruip et al., 1983), Golgi bodies were infrequent after GVBD. However, cortical granule numbers (Cran \& Cheng, 1985), as in other species, increase during late maturation (Zamboni, 1970; Sathananthan \& Trounson, 1982). Such an increase does not appear to be due to centrifugal migration (Cran \& Cheng, 1985). The Golgi has been shown to be the source of cortical granules in several species (Szollosi, 1967; Baca \& Zamboni, 1967; Zamboni, 1970; Kang, 1974; Kang \& Anderson, 1975; Selman \& Anderson, 1975). In the pig, however, continued production of 
granules could not be from multi-layer Golgi bodies. At $30-40 \mathrm{~h}$ after hCG extensive lengths of ER were present lying parallel to the plasma membrane. This was often associated with numerous small vesicles. While definitive evidence is lacking, this may represent a specialized form of Golgi involved in cortical granule formation.

I thank Mr W. T. K. Cheng for the ovariectomies and Mrs L. Musk for skilled technical assistance.

\section{References}

Ainsworth, L., Tsang, B.K., Downey, B.R., Marcus, G.J. \& Armstrong, D.T. (1980) Interrelationships between follicular fluid steroid levels, gonadotropic stimuli, and oocyte maturation during preovulatory development of porcine follicles. Biol. Reprod. 23, 621-627.

Baca, M. \& Zamboni, L. (1967) The fine structure of human follicular oocytes. J. Ultrastr. Res. 19, 354381.

Cran, D.G. \& Cheng, W.T.K. (1985) Changes in cortical granules during porcine oocyte maturation. Gamete Res. 11, (in press).

Cran, D.G., Moor, R.M. \& Hay, M.F. (1980) Fine structure of the sheep oocyte during antral follicle development. J. Reprod. Fert. 59, 125-132.

Crosby, I.M., Osborn, J.C. \& Moor, R.M. (1981) Follicle cell regulation of protein synthesis and developmental competence of sheep oocytes. J. Reprod. Fert. 62, 575-582.

Dekel, N., Hultborn, R., Hillensjo, R., Hamberger, L. \& Kraicer, P. (1976) Effect of luteinizing hormone on respiration of the preovulatory cumulus oophorus of the rat. Endocrinology 98, 498-504.

Dulbecco, R. \& Vogt, M. (1954) Plaque formation and isolation of pure lines with poliomyelitis virus. J. exp. Med. 99, 167-182.

Dziuk, P.J. \& Polge, C. (1962) Fertility in swine after induced ovulation. J. Reprod. Fert. 4, 207-208.

Edwards, R.G. (1965) Maturation in vitro of mouse, sheep, cow, pig, rhesus monkey and human ovarian oocytes. Nature, Lond. 208, 349-351.

Fleming, W.N. \& Saake, R.G. (1972) Fine structure of the bovine oocyte from the mature Graaafian follicle. $J$. Reprod. Fert. 29, 203-213.

Foote, W.D. \& Thibault, C. (1969) Recherches experimentales sur la maturation in vitro des oocytes de truie et de veau. Annls Biol. anim. Biochim. Biophys. 9, 329349.

Golbus, M.S. \& Stein, M.P. (1978) Qualitative patterns of protein synthesis in the mouse oocyte. J. exp. Zool. 198, 337-342.

Hadek, R. (1969) Mammalian Fertilization. Academic Press, New York.

Hancock, J.L. (1959) Polyspermy of pig ova. Anim. Prod. 1, 103-106.

Hunter, R.H.F. \& Polge, C. (1966) Maturation of follicular oocytes in the pig after injection of human chorionic gonadotrophin. J. Reprod. Fert. 12, 525531.

Kang, Y.H. (1974) Development of the zona pellucida in the rat oocyte. Am. J. Anat. 139, 535-566.

Kang, Y.H. \& Anderson, W.A. (1975) Ultrastructure of the oocytes of the Egyptian spiny mouse (Acomys cahirinus). Anat. Rec. 182, 175-200.
Kruip, T.A.M., Cran, D.G., van Beneden, T.H. \& Dieleman, S.J. (1983) Structural changes in bovine oocytes during final maturation in vivo. Gamete Res. 8, 29-47.

Lieberman, M.E., Tsafriri, A., Bauminger, S., Collins, N.P., Ahren, K. \& Lindner, H.A. (1976) Oocyte meiosis in cultured rat follicles during inhibition of steroidogenesis. Acta endocr., Copenh. 83, 151-157.

Magnusson, C., Hillensjo, T., Tsafriri, A., Hultborn, R. \& Ahren, K. (1977) Oxygen consumption of maturing rat oocytes. Biol. Reprod. 17, 9-15.

McGaughey, R.W. \& van Blerkom, J. (1977) Patterns of polypeptide synthesis of porcine oocytes during maturation in vivo. Devl Biol. 56, 241-254.

Moor, R.M. (1978) Role of steroids in the maturation of ovine oocytes. Annls Biol. anim. Biochim. Biophys. 18, 477-482.

Moor, R.M. \& Trounson, A.O. (1977) Hormonal and follicular factors affecting maturation of sheep cocytes in vitro and their subsequent developmental capacity. J. Reprod. Fert. 49, 101-109.

Moor, R.M. \& Wames, G.M. (1978) Regulation of oocyte maturation in mammals. In Control of Ovulation, pp. 159-176. Eds D. B. Crighton, G. R. Foxcroft, N. B. Haynes \& G. E. Lamming. Butterworths, London.

Moor, R.M., Hay, M.F., Dott, H.M. \& Cran, D.G. (1978) Macroscopic identification and steroidogenic function of atretic follicles in sheep. J. Endocr. 77, 309318.

Moor, R.M., Polge, C. \& Willadsen, S.M. (1980) Effect of follicular steroids on the maturation and fertilization of mammalian oocytes. J. Embryol. exp. Morph. 56, 319-335.

Moor, R.M., Osborn, J.C., Cran, D.G. \& Walters, D.E. (1981) Selective effect of gonadotrophins on cell coupling, nuclear maturation and protein synthesis in mammalian oocytes. J. Embryol. exp. Morph. 61, 347365.

Pincus, G. \& Enzmann, E.V. (1935) The comparative behaviour of mammalian eggs in vivo and in vitro. I. The activation of ovarian eggs. J. exp. Med. 62, 665675.

Polge, C. (1982) Embryo transplantation and preservation. In Control of Pig Reproduction, pp. 277-291. Eds D. J. A. Cole \& G. R. Foxcroft. Butterworths, London.

Russe, I. (1975) Unfertilized sheep eggs. J. Reprod. Med. 14, 200-204.

Sathananthan, A.H. \& Trounson, A.O. (1982) Ultrastructural observations on cortical granules in human follicular cocytes cultured in vitro. Gamete Res. 5, 191-198.

Selman, S. \& Anderson, E. (1975) The formation and 
cytochemical characterization of cortical granules in ovarian oocytes of the golden hamster (Mesocricetus auratus). J. Morph. 147, 251-274.

Senger, P.L. \& Saake, R.G. (1970) Unique mitochondria in the bovine oocyte. J. Cell Biol. 46, 405-408.

Sotelo, J.R. \& Porter, K.R. (1959) An electron microscopic study of the rat ovum. J. Biophys. Biochem. Cytol. 5, 327-342.

Spalding, J.F., Berry, R.O. \& Moffit, J.G. (1955) The maturation process of the ovum of swine during normal and induced ovulations. J. Anim. Sci. 14,609620.

Szollosi, D. (1967) Development of cortical granules and the cortical reaction in rat and hamster eggs. Anat. Rec. 159, 431-446.

Szollosi, D. \& Hunter, R.H.F. (1973) Ultrastructural aspects of fertilization in the domestic pig: sperm penetration and pronucleus formation. J. Anat. 116, $181-206$.

Thibault, C. (1977) Are follicular maturation and oocyte maturation independent processes? J. Reprod. Fert. 51, 1-15.

Thibault, C., Gerard, M. \& Menezo, Y. (1976) Nuclear and cytoplasmic aspects of mammalian oocyte maturation in vitro in relation to follicle size and fertilization. In Sperm Action, pp. 233-240. Ed. P. O. Hubinont. S. Karger, Basel.

Tsafriri, A., Lindner, H.R., Zor, U. \& Lamprecht, S.A. (1972) In vitro induction of meiotic division in follicle enclosed rat oocytes by LH, cyclic AMP and prostaglandin $\mathrm{E}_{2}$. J. Reprod. Fert. 31, 39-50.

Warnes, G.M., Moor, R.M. \& Johnson, M.H. (1977) Changes in protein synthesis during maturation of sheep cocytes in vivo and in vitro. J. Reprod. Fert. 49, 331-335.

Weibel, E.R. (1969) Stereological principles for morphometry in electron microscope cytology. Int. Rev. Cytol. 26, 235-302.

Weibel, E.R. \& Gomez, D.M. (1962) A principle for counting tissue structures on random sections. J. appl. Physiol. 17, 343-348.

Williams, M.A. (1977) Quantitative methods in biology. In Practical Methods in Electron Microscopy, vol. 6, pt II, pp. 5-84. Ed. A. M. Glauert. North-Holland Publishing Co., Amsterdam.

Zamboni, L. (1970) Ultrastructure of mammalian oocytes and ova. Biol. Reprod., Suppl. 2, 44-63.

Received 17 October 1984 